\title{
PENERAPAN PEMBELAJARAN KOOPERATIF TIPE TEAM \\ QUIZ UNTUK MENINGKATKAN HASIL BELAJAR SISWA \\ KELAS VI SDN NEGERI 2 KOTA BIMA PADA MATA PELAJARAN PENDIDIKAN AGAMA ISLAM
}

\author{
Oleh: \\ Aris Munandar \\ Sekolah Dasar Negeri 02 Kota Bima \\ Email: arismunandarndar643@gmail.com
}

\begin{abstract}
Abstrak
Penelitian ini dilakukan berdasarkan hasil observasi, rendahnya prestasi belajar (kognitif) siswa kelas VI SDN 2 Kota Bima pada mata pelajaran PAI. Oleh karena itu, penelitian ini bertujuan untuk menemukan upaya meningkatkan prestasi belajar (kognitif) siswa melalui penerapan Kooperatif Tipe Team Quiz. Adapun subjek dalam penelitian ini adalah siswa kelas VI SDN 2 Kota Bima sebanyak 40 orang, terdiri dari 27 siswa perempuan dan 13 siswa laki-laki. Jenis penelitian yang digunakan adalah penelitian tindakan kelas (Classroom Action Research) dengan proses tindakan kelas dilaksanakan sebanyak empat siklus namun di dalam tulisan ini penulis hanya menjelaskan 1 siklus saja. Setiap siklus terdiri dari 4 tahapan yang berkesinambungan yaitu: (1) perencanaan, (2) pelaksanaan, (3) observasi, dan (4) refleksi. Data aktivitas guru dan siswa dikumpulkan dengan menggunakan teknik observasi dan prestasi belajar (kognitif) siswa dikumpulkan melalui hasil tes (soal pilihan ganda dan essay) pada setiap akhir siklus. Adapun hasil temuannya Terjadi peningkatan kemampuan guru dalam mengelola proses pembelajaran di kelas VI SDN 2 Kota Bima pada mata pelajaran Pendidikan Agama Islam melalui penerapan Pembelajaran Kooperatif tipe Team Quiz Peningkatan aktivitas guru dalam menerapkan metode TQ ini terlihat pada presentase, yakni pada siklus I baru mencapai 61,11\%, dan Penerapan Pembelajaran Kooperatif tipe Team quiz dalam melihat aktifitas siswa kelas VI SDN 2 Kota Bima dalam menjalankan diskusi dalam pembelajaran Pendidikan Agama Islam dapat terlihat pada presentase ketuntasan yaitu pada siklus I mencapai $61,11 \%$.
\end{abstract}

Kata Kunci: Pembelajaran, Tipe Team Quiz, Hasil Belajar

\section{Pendahuluan}

Pendidikan adalah usaha sadar untuk mengembangkan potensi sadar untuk menumbuh kembangkan potensi Sumber Daya Manusia (SDM) melalui kegiatan pengajaran. Pendidikan diartikan sebagai suatu proses bantuan yang diberikan sumber belajar kepada peserta didik untuk memperoleh pengetahuan dan keterampilan agar peserta didik 
dapat mengalami perubahan pada dirinya. ${ }^{1}$ Ada dua konsep pendidikan yang saling terkaitan yaitu belajar (Learning) dan pembelajaran (Instruction). Konsep belajar berakar pada pihak pendidik. Pendidikan dapat ditempuh melalui jalur formal dan nonformal.

Pendidikan formal merupakan pendidikan yang dimulai dari jenjang terendah hingga tertinggi yang harus ditempuh dengan serangkaian persyaratan tertentu jika akan naik kejenjang selanjutnya. Pendidikan nonformal merupakan jenjang pendidikan yang diperoleh dalam sebuah lembaga pendidikan yang berorientasi memberi dan meningkatkan keterampilan yang dibutuhkan untuk berkompetisi dalam meraih kesuksesan hidup. Mutu pendidikan yang baik yaitu diikuti dengan hasil belajar siswa yang baik pula.

Selain itu proses interaksi belajar perlu diterapkan dengan baik yang pada prinsipnya tergantung pada guru dan siswa. Guru dituntut untuk menciptakan suasana belajar mengajar yang efektif. Sedangkan siswa dituntut adanya semangat dan dorongan untuk aktif dalam proses balajar mengajar. Sehingga keberhasilan belajar dalam bidang kognitif, afektif dan psikomotorik dapat tercapai oleh siswa itu sendiri.

Untuk mencapai tujuan tersebut maka guru dituntut untuk mengetahui bagaimana cara menghemat proses pembelajaran dengan baik agar dapat memberikan pengalaman yang bermakna bagi siswa. Lingkungan belajar harus dirancang sedemikian rupa sehingga peserta didik diberi kesempatan untuk melatih kemampuannya dalam memecahkan masalah. Adapun pemecahan masalah tersebut, dilakukan melalui kegiatan mental sehingga siswa akan menemukan sendiri konsep maupun prinsip cara belajar yang efektif. ${ }^{2}$

Realitas yang terjadi bahwa, khususnya di SDN 2 Kota Bima kelas VI nilai kebanyakan hasil belajar yang didapatkan siswa adalah dibawah rata-rata pada mata pelajaran pendidikan agama islam. Hal ini dikarenakan dari hasil observasi awal, yang diperoleh peneliti sendiri dan berbagai informasi dari guru mata pelajaran pendidikan agama islam dan sebagian siswa kelas VI di SDN 2 Kota Bima bahwa mata pelajaran pendidikan agama islam dianggap oleh sebagian siswa pelajaran yang membosankan, sehingga dampaknya siswa sulit menerima dan mencerna

\footnotetext{
${ }^{1}$ Hamalik, Guru dalam Proses Belajar Mengajar (Bandung: Sinar Baru Algensindo, 2009), 21.

${ }^{2}$ Depdiknas, Metode Pembelajaran Kewarganegaraan. (Jakarta: Direktorat Tenaga Kependidikan, 2005), 42.
} 
pelajaran pendidikan agama islam dan juga siswa nekat untuk bolos dampaknya hasil belajar yang diharapkan tidak dapat tercapai. Hal ini dapat terlihat pada tabel nilai tengah semseter ganjil.

Tabel 1.1 Nilai tengah semester ganjil kelas VI SDN 2 Kota Biam Tahun Ajaran 2019/2020.

\begin{tabular}{|c|c|c|c|c|}
\hline Kelas & $\begin{array}{c}\text { Nilai } \\
\text { tertinggi }\end{array}$ & $\begin{array}{c}\text { Nilai } \\
\text { terendah }\end{array}$ & $\begin{array}{c}\text { Nilai Rata- } \\
\text { Rata }\end{array}$ & $\begin{array}{c}\text { Ketuntasan } \\
\text { Klasikal }\end{array}$ \\
\hline VI & 90 & 40 & 64,89 & $56,41 \%$ \\
\hline
\end{tabular}

Sumber: Guru mata pelajaran PAI SDN 2 Kota Bima.

Selama ini kegiatan yang dilakukan siswa pada saat proses belajar lebih banyak hanya mendengar apa yang disampaikan guru. Komunikasi yang terjadi adalah komunikasi satu arah, yaitu guru kepada siswa. Dengan pembelajaran satu arah menimbulkan kebosanan bagi siswa, sehingga semangat siswa untuk mempelajari pelajaran pendidikan agama islam berkurang.

Banyak sekali metode pembelajaran yang dapat digunakan dalam proses belajaran mengajar. Agar hasil yang dicapai memuaskan diperlukan metode pembelajaran yang tepat, yaitu metode yang dapat membangkitkan hasil belajar dan pemahaman siswa terhadap mata pelajaran pendidikan kewarganegaraan, agar hasil belajar siswa tercapai. Salah satu upaya untuk meningkatkan hasil belajar dan pemahaman siswa pada mata pelajaran pendidikan agama islam yaitu dengan penggunaan metode belajar aktif tipe team quiz.

Pembelajaran tipe team quiz merupakan salah satu pembelajaran aktif yang dikembangkan oleh Mel Silberman dimana siswa dibagi kedalam tiga tim. Setiap siswa dalam tim bertanggung jawab untuk menyiapkan kuis jawaban dan tim yang lain menggunakan waktu untuk memeriksa catatannya. Dengan adanya pertandingan akademis ini terciptalah kompetisi antar kelompok, para siswa akan senantiasa berusaha belajar dengan motivasi yang tinggi agar dapat memperoleh nilai yang tinggi dalam pertandingan.

Dan siswa akan memiliki semangat untuk belajar pelajaran pendidikan kewarganegaraan. Dengan adanya permasalahan yang dikemukakan di atas maka proses pembelajaran pokok bahasan "Nilainilai ajaran islam"yaitu dengan metode belajar aktif tipe team quiz. Metode team quiz ini diawali dengan menerangkan materi pelajaran secara klasikal, lalu siswa dibagi kedalam kelompok besar. Semua 
anggota kelompok bersama-sama mempelajari materi tersebut melalui lembaran kerja.

Mereka mendiskusikan materi tersebut, saling memberi arahan ,saling memberikan pertanyaan dan jawaban untuk memahami materi tersebut. Setelah selesai materinya maka diadakan suatu pertandingan akademis. Sehingga siswa termotivasi untuk belajar. Apabila dalam proses pembelajaran pendidikan agama islam dibuat menyenangkan, dimana penggunaan metode belajar yang tepat dan dapat membangkitkan minat serta pemahaman siswa pada pendidikan agama islam, maka siswa akan merasa lebih senang dan tidak bosan dalam mengikuti kegiatan pembelajaran. Sehingga tidak ada lagi keluhan rendahnya hasil belajar siswa pada pendidikan agama islam.

Berdasarkan latar belakang dari berbagai permasalahan yang terjadi diatas peneliti tertarik untuk melakukan penelitian tindakan kelas dengan mengangkat judul "Penerapan Model Pembelajaran Kooperatif Tipe Team Quiz untuk Meningkatkan Hasil Belajar Siswa pada mata pelajaran Pendidikan Agama Islam Kelas VI Di SDN 2 Kota Bima Tahun Pembelajaran 2019/2020.

\section{Landasan Teoritis}

1. Pembelajaran Kooperatif

a. Pengertian Pembelajaran Kooperatif

Pembelajaran kooperatif menggunakan sistem pengelompokan yang terdiri dari tiga,empat sampai enam orang yang mempunyai kemampuan akademik, jenis kelamin, suku yang heterogen. ${ }^{3}$ Pada proses pembelajaran siswa diberi kesempatan bekerja dalam kelompok kecil untuk mendiskusikan atau memecahkan masalah. Tugas kelompok dapat memacu para siswa untuk bekerja sama dalam mengintergrasikan pengetahuan baru dengan pengetahuan yang telah dimilikinya. Pembelajaran kooperatif merupakan model pembelajaran yang mengutamakan kerjasama diantara siswa untuk mencapai tujuan pembelajaran.

Model pembelajaran kooperatif adalah salah satu model pembelajaran yang menempatkan siswa sebagai subjek pembelajaran (student oriented). Dengan suasana kelas yang demokratis, yang saling membelajarkan memberi kesempatan

\footnotetext{
${ }^{3}$ Hamalik, Proses Belajar Mengajar. (Jakarta: Sinar Grafindo Offset, 2004), hlm. 24.
} 
peluang lebih besar dalam memberdayakan potensi siswa secara maksimal. ${ }^{4}$

Jadi pembelajaran kooperatif adalah suatu sistim pengelompokan siswa yang memiliki berbagai karakter yang terdiri dari tiga, empat, sampai enam kelompok, yang menekankan pada sikap atau perilaku bersama dalam bekerja atau membantu di antara sesama dalam struktur kerjasama yang teratur dalam kelompok

b. Ciri-ciri Pembelajaran Kooperatif

$$
\text { Menurut Suprijono Ciri-Ciri Pembelajaran }
$$

Kooperatif adalah sebagai berikut : ${ }^{5}$

a) Siswa belajar dalam kelompok, aktif mendengar, dan mengemukakanpendapat.

b) Membuat keputusan secara bersama

c) Kelompok siswa terdiri dari siswa-siswa yang memiliki kemampuantinggi, sedang, dan rendah.

d) Jika didalam kelas terdapat siswa yang terdiri dari berbagai ras, suku,agama, budaya, dan jenis kelamin yang berbeda, maka diupayakanagar dalam setiap kelompok pun terdapat ras, suku, agama, dan jeniskelamin yang berbeda pula.

e) Penghargaan lebih diutamakan pada kerja kelompok dari pada kerjaperorangan.

Jadi dapat ditarik kesimpulan menurut para ahli diatas bahwa ciri-ciri pembelajaran kooperatif adalah bagaimana menuntaskan materi yang menjadi topik diskusi, bekerja sama secara kolektif dan kolegial dalam artian bahwa tidak ada yang lebih menonjolkan sifat individual tapi bagaimana siswa itu mampu menerima perbedaan pada diri siswa itu sendiri dan kemudian saling bahu membahu dalam menuntaskan masalah.

c. Tujuan Pembelajaran Kooperatif

Tujuan pembelajaran kooperatif berbeda dengan kelompok konvensional yang menerapkan sistem kompetisi, di mana keberhasilan individu diorientasikan pada kegagalan orang lain. Sedangkan tujuan dari pembelajaran kooperatif adalah

\footnotetext{
${ }^{4} \mathrm{http}: / / \mathrm{www}$. idonbiu.com/2009/05/pembelajarancooperativelearning. html

${ }^{5}$ Suprijono, Pendidikan Bagi Anak Berkesulitan Belajar (Jakarta: PT Rineka Cipta, 2009), hlm. 5.
} 
menciptakan situasi di mana keberhasilan individu ditentukan atau dipengaruhi oleh keberhasilan kelompoknya. ${ }^{6}$

Menurut Hamalik pengelolaan pembelajaran dengan menggunakan strategi pembelajaran kooperatif, paling tidak ada tujuan yng hendak dicapai yaitu :

1) Hasil belajar akademik

Pembelajaran kooperatif bertujuan untuk menigkatkan kinerja siswa dalam tugas akademik. Banyak ahli berpendapat bahwa model kooperatif unggul dalam membantu siswa dalam memahami konsep-konsep yang sulit.

2) Pengakuan adanya keragaman

Model kooperatif bertujuan agar siswa dapat menrima teman-temannya yang mempunyai berbagai macam perbedaan latar belakang. Perbedaan tersebut antara lain perbedaan suku, agama, kemampuan akademik, dan tingkat sosial.

3) Pengembangan keterampilan sosial

Pembelajaran kooperatif bertujuan untuk mengembangkan keterampilan siswa. Keterampilan sosial yaang dimaksud antara lain : berbagi tugas, aktif bertanya,menghargai pendapat orang lain, mau menjelaskan ide atau pendapat dan bekerja dalam kelompok.

Dari pemaparan diatas dapat disimpulkan bahwa tujuan pembelajaran kooperatif adalah untuk mengajarkan kepada siswa keterampilan kerjasama dan kolaborasi untuk menciptakan situasi dimana keberhasilan individual dipengaruhi oleh keberhasilan kelompoknya untuk mencapai hasil akademik.

2. Pembelajaran Kooperatif Tipe Team Quiz

Metode team quiz merupakan salah satu metode pembelajaran bagi sisiwa yang membangkitkan semangat dan pola pikir kritis. Secara definisi metode team quiz yaitu suatu metode yang bermaksud melempar jawaban dari kelompok satu ke kelompok lain. ${ }^{8}$ Tipe team quiz merupakan model pembelajaran aktif yang dikembangkan oleh Mel Siberman, yang mana dalam tipe team quiz ini siswa dibagi menjadi tiga tim. Setiap siswa dalam tim bertanggung jawab untuk

\footnotetext{
${ }^{6}$ Slavin, Cooperative LearningTeori, Riset, dan Praktik (Bandung: Nusa Media, 2008), hlm. 20.

${ }^{7}$ Hamalik, Proses Belajar Mengajar..., hlm. 25.

${ }^{8}$ Suyanto, Menjelajah Pembelajaran Inovatif (Surabaya: Masmedia Buana Pustaka, 2009), hlm. 19.
} 
mmenyiapkan kuis jawaban singkat, dan tim yang lain menggunakan waktunya untuk memeriksa catatan. ${ }^{9}$

Dalam tipe team quiz ini, diawali dengan guru merangkan materi secara klasikal lalu siswa dibagi kedalam tiga kelompok besar. Semua anggota kelompok bersama-sama mempelajari materi tersebut, saling memberi arahan, saling memberi pertanyaan dan jawaban untuk memahami mata pelajaran tersebut. Setelah selesai materi maka diaadakan suatu pertandingan akademis. ${ }^{10}$ Dengan adanya pertandingan akademis ini maka terciptalah kompetisi antar kelompok, para siswa akan senantiasa berusaha belajar dengan motivasi yang tinggi agar dapat memperoleh nilai yang tinggi dalam pertandingan.

Jadi dapat disimpulkan bahwa metode team quiz adalah suatu model pembelajaran dengan membagi kelompok ke dalam tiga kelompok siswa dapat berperan secara langsung dan saling berinteraksi sehingga siswa dapat memecahkan masalah yang terjadi.

Langkah-langkah Penerapan Metode Team Quiz

Menurut Hamalik, Adapun langkah-langkah dari metode team quiz adalah : ${ }^{11}$

1) Guru membagi topik materi menjadi 3 segmen.

2) Guru membagi siswa menjadi 3 kelompok yaitu A, B, dan C

3) Guru menjelaskan format pembelajaran

4) Guru menyaampaikan materi topik 1. Usahakan ,waktu menjelaskan materi cukup dibatasi 10 menit.

5) Guru meminta kelompok A untuk menyusun pertanyaan yang berkaitan dengan materi, pada saat yang sama kelompok B dan C diminta mempelajari materi atau membuka catatannya.

6) Kelompok A diminta mengajukan pertanyaan kepada kelompok B untuk menjawabnya, jika kelompok $\mathrm{B}$ tidak bisa menjawab, pertanyaan dilempar kepada kelompok $\mathrm{C}$.

7) Kelompok A diminta mengajukan pertanyaan kepada kelompok B apabila tidak bisa menjawab maka untuk menjawab pertanyaan dilempar ke kelompok $\mathrm{C}$.

8) Setelah proses tanya jawab untuk topik satu selesai, guru menjelaskan topik dua.

\footnotetext{
${ }^{9}$ Suprijono, Pendidikan Bagi Anak Berkesulitan Belajar..., hlm. 16

${ }^{10}$ Ibid., hlm. 18.

${ }^{11}$ Hamalik, Proses Belajar Mengajar..., hlm. 39.
} 


\section{Hasil Belajar}

Hasil belajar perwujudan perilaku belajar yang biasanya terlihat dalam perubahan, kebiasaan, keterampilan, sikap, pengamatan dan kemampuan. Hasil belajar dapat dilihat dan diukur. Keberhasilan dalam proses belajar dapat dilihat dari hasil belajarnya. Hasil belajar adalah kemampuan yang dimiliki siswa setelah ia menerima pengalaman belajar. $^{12}$

Menurut Hamalik, hasil belajar adalah bila seseorang telah belajar akan terjadi perubahan tingkah laku pada orang tersebut, misalnya dari tidak tahu menjadi tahu, dan dari tidak mengerti menjadi mengerti. ${ }^{13}$ Hasil belajar menurut Sudjana adalah kemampuan yang dimiliki siswa setelah ia menerima pengalaman belajaranya. Jadi hasil belajar adalah akibat dari suatu aktivitas yang dapat diketahui perubahannya dalam pengetahuan, pemahaman, ketrampilan, dan nilai sikap melalui ujian tes. ${ }^{14}$

Rifa'i (2009:97) menyatakan bahwa faktor-faktor yang memberikan kontribusi terhadap proses dan hasil belajar adalah kondisi internal dan eksternal peserta didik. Kondisi internal mencakup kondisi fisik, seperti kesehatan organ tubuh; kondisi psikis seperti kemampuan intelektual, emosional;dan kondisi sosial, seperti kemampuan bersosialisasi dengan lingkungan. Sama kompleksnya pada kondisi internal adalah kondisi eksternal yang ada dilingkungan peserta didik. Beberapa faktor eksternal seperti variasi dan tingkat kesulitan materi belajar (Stimulus) yang dipelajari (direspon), tempat belajar,iklim, suasana lingkungan, dan budaya belajar masyarakat akan mempengaruhikesiapan, proses, dan hasil belajar. ${ }^{15}$

Para ahli mengenai faktor-faktor diatas makadapat disimpulkan bahwa hasil belajar akuntansi dapat dipengaruhi oleh duafaktor utama yaitu faktor internal dan juga faktor eksternal, yang mana faktorinternal merupakan faktor-faktor yang bersumber dari individu masing-masingsiswa, sedangkan faktor eksternal yaitu faktor-faktor yang bersumber dari luarindividu siswa itu sendiri. Berkaitan dengan proses belajar mengajar ada satufaktor penting yang

\footnotetext{
${ }^{12}$ Sudrajat, Evaluasi Hasil Belajar (Surabaya: Usaha Nasional, 2006), hlm. 22.

${ }^{13}$ Hamalik, Proses Belajar Mengajar..., hlm. 30.

${ }^{14}$ Sudjana, Metode Pengajaran Nasional (Bandung: Jemmars, 1990), hlm. 22.

${ }^{15}$ Rifa'i, Belajar dan Faktor- faktor yang Mempengaruhinya (Jakarta: Rineka Cipta, 2009), hlm. 97.
} 
sangat berpengaruh terhadap hasil belajar siswa yaitu faktor pemilihan metode pembelajaran. Faktor ini sangat penting karena pemilihanmetode pembelajaran yang tepat oleh guru akan mempengaruhi antusiasme parasiswa dalam mengikuti proses pembelajaran.Metode pembelajaran harus disusun sedemikian rupa, sehingga pesertadidik tidak merasa bosan dan jenuh dengan metode pembelajaran yangberlangsung. Selain penyusunan metode pembelajaran yang baik, juga diperlukanbeberapa variasi cara mengajar guru untuk meminimalisir tingkat kejenuhan siswa.

4. Kerangka Berpikir

Selama ini dalam melakukan pembelajaran PAI guru masih menggunakan metode pembelajaran konvensional, yaitu metode cermah yang sekali-kali divariasiakn dengan metode lain, seperti metode tanya jawab dan pemberian latihan soal. Metode ini memposisikan siswa sebagai objek pembelajaran dan guru sebagai pusat kegiatan belajar.

Metode belajar konvensional yaitu metode pembelajaran dengan ceramah, tanya jawab dan latihan soal. Menurut Slavin (metode ini cenderung menjadikan suasana belajar kaku, monoton dan kurang menggairahkan, sehingga siswa menjadi kurang aktif dan tidak bersemangat dalam belajar. Untuk membangkitkan semangat siswa dalam belajar adalah dengan penggunaan metode belajar yang tepat. ${ }^{16}$

Salah satu metode belajar yang dapat digunakan pada proses belajar mengajar adalah metode team quiz guru dimana menerangkan materi secara klasikal lalu siswa dibagi kedalam tiga kelompok besar. Semua anggota kelompok bersama-sama mempelajari materi tersebut, saling memberi arahan, saling memberi pertanyaan dan jawaban untuk memahami mata pelajaran tersebut. Setelah selesai materi maka diadakan suatu pertandingan akademis. Dengan adanya pertandingan akademis ini, maka terciptalah kompetisi antar kelompok, para siswa akan senantiasa berusaha belajar dengan motivasi yang tinggi agar dapat memperoleh nilai yang tinggi dalam pertandingan.

Dalam perbuatan belajar, perubahan-perubahan itu senantiasa bertambah dan tertuju untuk memperoleh sesuatu yang lebih baik dari sebelumnya. Selain itu juga dapat meningkatkan pemahaman siswa terhadap mata pelajaran PAI sehingga menghasilkan suasana belajar

\footnotetext{
${ }^{16}$ Slavin, Cooperative LearningTeori, Riset, dan Praktik..., hlm. 34.
} 
yang menyenangkan bagi siswa dan terhindar dari rasa jenuh dan bosan.

Ketika siswa memiliki rasa menyenangkan maupun ketertarikan dalam mengikuti pelajaran PAI, maka apa yang telah disampaikan oleh guru akan mudah diserap dan dicerna oleh siswa itu sendiri dan kemudian hasil belajar pun akan meningkat. Karena ketika metode team quiz ini diterapkan tidak hanya guru saja yang aktif dalam kelas tetapi siswa juga akan secara langsung berperan aktif dalam mendiskusikan suatu masalah dengan teman sekelompoknya karena kepemilikan rasa tanggung jawab terhadap kelompok sangat tinggi.

Sehingga siswa mampu untuk terlibat secara langsung dapat saling berinteraksi, saling bertukar ide, saling berdiskusi, dan saling memunculkan strategi-strategi untuk memecahkan setiap permasalahan yang dihadapi dalam proses belajar mengajar. Berdasarkan uraian diatas bahwa Metode Pembelajaran Kooperatif tipe Team Quiz dapat mengatasi permasalahan yang dialami siswa sehingga dengan adanya penerapan Metode Team Quiz ini diduga mampu meningkatkan prestasi belajar siswa.

\section{Metodologi Penelitian}

Penelitian ini menggunakan rancangan Class Room Reseach atau penelitian tindakan kelas yang didalamnya terbentuk dari rangkaian siklus kegiatan, karena didasarkan pada masalah yang dihadapi oleh guru didalam kelas diantaranya minat siswa dan hasil belajar siswa, serta bertujuan untuk memperbaiki dan meningkatkan kualitas instruksional. Penelitian tindakan kelas merupakan suatu pencermatan terhadap kegiatan belajar berupa sebuah tindakan, yang sengaja dimunculkan dan terjadi dalam sebuah kelas secara bersama. ${ }^{17}$

Dari pendapat diatas dapat disimpulkan bahwa dalam penelitian ini menggambarkan bagaimana suatu tekhnik pembelajaran diterapkan dan bagaimana hasil yang ingin dicapai dan meningkatkan pemantapan dalam melaksanakan tugas serta memperdalam pemahaman terhadap tindakan-tindakan yang dilakukan.

Dalam penelitian ini, pelaksanaan dilakukan sebanyak 3 (tiga) siklus, masing-masing siklus dilaksanakan sebanyak 1 kali pertemuan. Dengan menerapkan model PTK Kemmis dan Mc Taggart yang terdiri

\footnotetext{
${ }^{17}$ Suharsimi Arikunto, Penelitian TindakanKelas (Jakarta: BumiAksara, 2010), hlm. 3.
} 
dari empat komponen pokok yaitu: (1) perencanaan (Planning),(2) pelaksanaan/tindakan (Action),(3) pengamatan (Observing), (4) refleksi (Reflecting).

\section{Pembahasan}

Penelitian ini dilakukan sebanyak 4 siklus, namun dalam tulisan ini penulis hanya bisa menjelaskan sebanyak 1 siklus saja disebabkan karena pembahasannya sangat panjang, dan masing-masing siklus terdiri dari beberapa tahapan yaitu: tahap perencanaan, tahap pelaksanaan, tahap observasi, tahap refleksi. Adapun paparan data setiap siklus adalah sebagai berikut:

1. Data Siklus 1

Siklus pertama dilaksanakan pada tanggal 12 Juli dan 26 Juli 2019. Langkah-langkah yang dilakukan pada siklus pertama sebagai berikut :

a. Tahap Perencanaan

Pada tahap ini dilakukan beberapa perencanaan sebelum siklus-siklus dilaksanakan. Perencanaan ini meliputi: (1) menyiapkan bahan ajar yaitu materi yang akan didiskusikan siswa tentang Nilai-nilai ajaran islam dengan sub pokok islam sebagai agama yang rahmatan lil alamin, yang sekaligus akan menjadi bahan untuk diskusi kelompok siswa (2) Menyusun RPP sesuai model pembelajaran kooperatif tipe Team Quiz (terlampir), (3) Quiz/ tes yaitu instrumen untuk mengetahui hasil belajar siswa, yang terdiri dari soal pilihan ganda (terlampir), (5) Pedoman observasi yaitu untuk melihat bagaimana aktivitas siswa dan guru ketika diterapkan model pembelajaran Kooperatif tipe Team Quiz.

b. Tahap Pelaksanaan

Pada tahap ini, implementasi Rancangan Pembelajaran yang telah disusun oleh peneliti berdasarkan Pembelajaran kooperatif tipe Team Quiz dengan materi pelajaran tentang Nilainilai ajaran islam dengan sub pokok islam sebagai agama yang rahmatan lil alamin. Pada siklus pertama ini dilaksanakan selama dua kali pertemuan dengan rincian: Pertemuan pertama, guru memberikan gambaran tentang model pembelajaran yang akan dilaksanakan yaitu Guru membagi topik materi menjadi 3 segmen maksudnya materi yang menjadi bahan ajar, kemudian guru membagi siswa menjadi 3 kelompok yaitu A, B, dan C, Guru menjelaskan format pembelajaran, Guru menyampaikan materi 
topik 1. Usahakan, waktu menjelaskan materi cukup dibatasi 10 menit, kemudian guru meminta kelompok A untuk menyusun pertanyaan yang berkaitan dengan materi, pada saat yang sama kelompok $\mathrm{B}$ dan $\mathrm{C}$ diminta mempelajari materi atau membuka catatannya, Kelompok A diminta mengajukan pertanyaan kepada kelompok B untuk menjawabnya, jika kelompok B tidak bisa menjawab, pertanyaan dilempar kepada kelompok C. Kelompok A diminta mengajukan pertanyaan kepada kelompok B apabila tidak bisa menjawab maka untuk menjawab pertanyaan dilempar ke kelompok C. Setelah proses tanya jawab untuk topik satu selesai, guru menjelaskan topik dua, Mintailah kelompok B sebagai penyusun pertanyaan, sedangkan kelompok $\mathrm{A}$ dan $\mathrm{C}$ sebagai kelompok penjawab, kemudian langkah yang sama untuk topik tiga dengan cara kelompok $\mathrm{C}$ sebagai penyusun pertanyaan sedangkan kelompok A dan B sebagai penjawab.

Dalam hal ini, guru hanya memiliki kedudukan sebagai arahan untuk membimbing siswa agar diskusi berjalan dengan lancar, suasana diskusi hanya dilakukan oleh siswa itu sendiri dengan mencari pemecahan masalah yang terjadi dalam kelompok, siswa pun disini diajarkan untuk bekerja secara kolektif tidak berindividu karena mereka adalah satu team yang harus kompak. Pada tahap pertama ini, siswa masih bingung dengan arahan yang disampaikan sehingga ada siswa yang acuh tak acuh mendengarkan akhirnya dampak pada kelompoknya sendiri dengan tidak mau bekerja sama serta tidak aktif sama sekali.

Pertemuan kedua, pada pertemuan ini siswa di dalam masing-masing kelompok menunjuk ketua kelompok agar mempresentasikan kepada kelompok lain yaitu hasil ringkasan materi bersama kelompoknya beserta menyiapkan pertanyaan yang akan diberikan kepada kelompok lain, kemudian kelompok lain menyimak dengan seksama. Begitu pun selanjutnya. Kemudian di akhir siklus guru memberikan soal tes sebagai indikator hasil belajar siswa yaitu dengan bentuk pilihan ganda secara individu tanpa ada kerjasama dengan kelompok.

c. Tahap Observasi

Pada tahap ini, penilaian terhadap aktivitas siswa dan guru sebagai peneliti dibantu oleh observer itu sendiri yaitu guru pamong dan mahasiswa, observasi ini dilaksanakan ketika kegiatan 
proses belajar mengajar berlangsung. Aktivitas siswa diteliti oleh peneliti sedangkan observasi aktivitas peneliti di amati oleh guru itu sendiri.

Adapun hasil observasi pada siklus I dapat dilihat sebagai berikut :

a) Data aktivitas guru

Data hasil observasi aktivitas guru dalam pelaksanaan pembelajaran di kelas sesuai dengan rancangan pembelajaran model pembelajaran kooperatif tipe Team Quiz, yang termasuk dalam kategori cukup sesuai dengan indikator capaian dapat dilihat pada Tabel 4.1 (selengkapnya dapat dicermati pada lampiran).

Tabel 4.1. Data aktivitas guru pada pelaksanaan model pembelajaran

Kooperatif tipe team quiz (Siklus I)

\begin{tabular}{|c|l|c|c|c|}
\hline No. & \multicolumn{1}{|c|}{ Indikator } & $\begin{array}{c}\text { Jumlah } \\
\text { deskriptor }\end{array}$ & $\begin{array}{c}\text { Jumlah deskriptor } \\
\text { yang muncul }\end{array}$ & $\begin{array}{c}\text { Persentase } \\
(\%)\end{array}$ \\
\hline 1. & Persiapan & 2 & 2 & $11,76 \%$ \\
\hline 2. & Pendahuluan & 2 & 1 & $5,88 \%$ \\
\hline 3. & $\begin{array}{l}\text { Pengembang } \\
\text { an }\end{array}$ & 3 & 2 & $11,76 \%$ \\
\hline 4. & $\begin{array}{l}\text { Penerapan } \\
\text { pembelajaran }\end{array}$ & 6 & 3 & $17,64 \%$ \\
\hline 5. & Penutup & 4 & 2 & $11,76 \%$ \\
\hline \multicolumn{2}{|c|}{ Jumlah } & $\mathbf{1 7}$ & $\mathbf{1 0}$ & $\mathbf{5 2 , 9 4 \%}$ \\
\hline
\end{tabular}

Tabel 4.1. diatas menunjukan aktivitas guru dalam menerapkan model pembelajaran kooperatif tipe team quiz, hanya memenuhi indikator sebesar 52,94\%, dalam hal ini belum mencapai $90 \%$ deskriptor dengan jumlah keseluruhan 17 yang harus dikuasai dengan baik oleh guru, melainkan hanya mampu mencapai 10 desriptor saja yang baik, sedangkan 7 deskriptor masih dalam taraf cukup, diantaranya sebagai berikut :

1) Ketika pada tahap pendahuluan, guru kurang dalam menyampaikan tujuan pembelajaran.

2) Pada pelaksanaan diskusi kelompok, guru kurang dalam memotivasi setiap kelompok dalam mengerjakan tugas,

3) Guru kurang memberikan bimbingan kepada siswa dalam memecahkan dan memutuskan permasalahan dalam kelompok, 
4) Mendorong siswa untuk menyiapkan laporan akhir atau hasil kerja kelompoknya,

5) Mendorong siswa untuk mempresentasikan laporan akhir atau hasil kerja kelompoknya

6) Memotivasi siswa untuk saling mendukung dalam memaparkan hasil diskusi agar menjadi menarik,

7) Guru kurang mengevaluasi siswa terhadap topik-topik yang dibahas dalam diskusi kelompok.

b) Data aktifitas siswa pada saat pelaksanaan diskusi kelompok

Berdasarkan hasil observasi pada siklus I terkait

dengan aktifitas siswa, dapat dilihat pada Tabel 4.2 (selengkapnya dapat dicermati pada lampiran) di bawah ini:

Tabel 4.2: Data aktifitas siswa saat diskusi kelompok pada siklus I.

\begin{tabular}{|l|c|c|c|}
\hline No & Tingkat aktifitas siswa & Jumlah siswa & Persentase \\
\hline 1 & Sangat baik & 0 & 0 \\
\hline 2 & Baik & 22 & $61,11 \%$ \\
\hline 3 & Cukup & 12 & $33,33 \%$ \\
\hline 4 & Kurang & 4 & $11,11 \%$ \\
\hline
\end{tabular}

Berdasarkan data hasil observasi Aktifitas siswa dalam diskusi kelompok, terlihat masih kurang dan belum mampu untuk mencapai target yang telah ditetapkan dalam indikator capaian yaitu $85 \%$. Hal ini dapat dilihat pada Tabel 4.2 di atas, yaitu tingkat aktifitas siswa dalam kategori "sangat baik" tidak ada (0), pada kategori "baik" ada 22 siswa dengan presentase sebesar 61,11\%, kemudian pada kategori "cukup" ada 12 siswa dengan presentasenya 33,33\%, dan pada kategori "kurang" ada 4 orang dengan presentase sebesar $11,11 \%$. Hal ini disebabkan karena siswa terlihat masih bingung dan belum terbiasa untuk melaksanakan diskusi kelompok, terlebih dengan model pembelajaran yang baru diterapkan. Sehingga perlu untuk dilakukan siklus berikutnya guna untuk melihat aktifitas siswa dalam diskusi kelompok.

c) Data hasil belajar siswa pada siklus I

Setelah dilakukan Quiz/ tes untuk melihat hasil belajar siswa terkait dengan materi Nilai-nilai ajaran islam dengan sub pokok bahasan islam sebagai agama yang rahmatan lil alamin yang dilaksanakan pada tanggal 26 Juli 2019. Dapat dilihat pada 
Tabel 4.3 (selengkapnya dapat dicermati pada lampiran) di bawah ini:

1) Data hasil belajar siswa secara individu

Tabel 4.3. Data hasil belajar siswa secara individu siswa kelas VI SDN 2 Kota Bima tahun ajaran 2019-2020 (Siklus I)

\begin{tabular}{|c|l|c|c|c|}
\hline No & \multicolumn{1}{|c|}{ Nama Siswa } & $\begin{array}{c}\text { Skor } \\
(\mathbf{X})\end{array}$ & $\mathbf{x}$ (X-Mean) & $\mathbf{x}^{\mathbf{2}}$ \\
\hline 1 & Aan Hariadi & 55 & -18 & 324 \\
\hline 2 & Amila Difa & 70 & -3 & 9 \\
\hline 3 & Baiq Hartina & 75 & 2 & 4 \\
\hline 4 & Baiq Lola Mithaflianti & 65 & -8 & 64 \\
\hline 5 & Bayu Prajastia & 75 & 2 & 4 \\
\hline 6 & Dea Amelia & 75 & 2 & 4 \\
\hline 7 & Dewi Santika & 75 & 2 & 4 \\
\hline 8 & Dicki Zulkarnaen & 70 & -3 & 9 \\
\hline 9 & Dika Hendrawan & 65 & -8 & 46 \\
\hline 10 & Doni Dharma Aryatmaja & 80 & 7 & 49 \\
\hline 11 & Febrianto & 85 & 12 & 144 \\
\hline 12 & Fitri Ainun & 80 & 7 & 49 \\
\hline 13 & Gama Ramadhan Asqwa & 80 & 7 & 49 \\
\hline 14 & Hari Mulyadi Yulianto & 75 & 2 & 4 \\
\hline 15 & Helsan & 60 & -13 & 169 \\
\hline 16 & Hendrawan & 65 & -8 & 64 \\
\hline 17 & Lalu Bayu Rifki Aji & 80 & 7 & 49 \\
\hline 18 & M.Saopi & 70 & -3 & 9 \\
\hline 19 & Maesrah & 70 & -3 & 9 \\
\hline 20 & Maulina & 75 & 2 & 4 \\
\hline 21 & May Ayu Hairani & 75 & 2 & 4 \\
\hline 22 & Muliana & 65 & -8 & 64 \\
\hline 23 & Munip pahaswan & 70 & -3 & 9 \\
\hline 24 & Rahmat Haris & 70 & 12 & 144 \\
\hline 25 & Septiana & 75 & 2 & 9 \\
\hline 26 & Sanggarani Putri Adi Guna & 75 & 2 & 4 \\
\hline 27 & Siti Indah wahyuni & 75 & 2 & 4 \\
\hline 28 & Solatiah & 80 & 7 & 49 \\
\hline 29 & Syfa Bela Fajrin & 55 & -18 & 324 \\
\hline 30 & Wahyu Saputra & & 2 & 4 \\
\hline 31 & Widya Rosita Fajrin & & \\
\hline & & & -3 & 4 \\
\hline
\end{tabular}




\begin{tabular}{|c|l|c|c|c|}
32 & Wulan Suci Rmafhani Pratomo & 75 & 2 & 4 \\
\hline 33 & Yudha haristia & 80 & 7 & 49 \\
\hline 34 & Yudhi dwi Handika & 85 & 12 & 144 \\
\hline 35 & Maliki & 55 & -18 & 324 \\
\hline 36 & M. Gufran magribi & 80 & 7 & 49 \\
\hline \multicolumn{2}{|l|}{ Jumlah } & $\mathbf{2 6 2 0}$ & & $\mathbf{2 2 5 6}$ \\
\hline
\end{tabular}

$\mathrm{M}=\frac{\sum X}{n}$

$$
=\frac{2620}{36}
$$

$=72,78($ di bulatkan menjadi 73)

$$
\begin{aligned}
\mathrm{SD} & =\sqrt{\frac{\sum x^{2}}{n}} \\
& =\sqrt{\frac{2256}{36}} \\
& =\sqrt{62,67} \\
& =7,91(\text { di bulatkan menjadi } 8)
\end{aligned}
$$

Mengubah skor mentah menjadi nilai standar lima

$$
\begin{aligned}
& 85-97=\mathrm{A} \\
& 77-<85=\mathrm{B} \\
& 69-<77=\mathrm{C} \\
& 61-<69=\mathrm{D} \\
& 49-<61=\mathrm{E}
\end{aligned}
$$

Tabel 4.4. Data konversi skor mentah menjadi nilai standar lima

\begin{tabular}{|c|l|c|c|c|}
\hline No & \multicolumn{1}{|c|}{ Nama Siswa } & $\begin{array}{c}\text { Skor } \\
\text { Mentah }\end{array}$ & Nilai Huruf & Keterangan \\
\hline 1 & Aan Hariadi & 55 & E & Tidak tuntas \\
\hline 2 & Amila Difa & 70 & C & Tuntas \\
\hline 3 & Baiq Hartina & 75 & B & Tuntas \\
\hline 4 & Baiq Lola Mithaflianti & 65 & D & Tidak tuntas \\
\hline 5 & Bayu Prajastia & 75 & B & Tuntas \\
\hline 6 & Dea Amelia & 75 & B & Tuntas \\
\hline 7 & Dewi Santika & 75 & B & Tuntas \\
\hline 8 & Dicki Zulkarnaen & 70 & C & Tuntas \\
\hline 9 & Dika Hendrawan & 65 & D & Tidak tuntas \\
\hline
\end{tabular}




\begin{tabular}{|c|l|c|c|c|}
\hline 10 & Doni Dharma Aryatmaja & 80 & B & Tuntas \\
\hline 11 & Febrianto & 85 & A & Tuntas \\
\hline 12 & Fitri Ainun & 80 & B & Tuntas \\
\hline 13 & Gama Ramadhan Asqwa & 80 & B & Tuntas \\
\hline 14 & Hari Mulyadi Yulianto & 75 & B & Tuntas \\
\hline 15 & Helsan & 60 & D & Tidak tuntas \\
\hline 16 & Hendrawan & 65 & D & Tidak tuntas \\
\hline 17 & Lalu Bayu Rifki Aji & 80 & B & Tuntas \\
\hline 18 & M.Saopi & 70 & C & Tuntas \\
\hline 19 & Maesrah & 70 & C & Tuntas \\
\hline 20 & Maulina & 75 & B & Tuntas \\
\hline 21 & May Ayu Hairani & 75 & B & Tuntas \\
\hline 22 & Muliana & 65 & D & Tidak tuntas \\
\hline 23 & Munip pahaswan & 70 & C & Tuntas \\
\hline 24 & Rahmat Haris & 85 & A & Tuntas \\
\hline 25 & Septiana & 70 & C & Tuntas \\
\hline 26 & Sanggarani Putri Adi Guna & 75 & B & Tuntas \\
\hline 27 & Siti Indah wahyuni & 75 & B & Tuntas \\
\hline 28 & Solatiah & 75 & B & Tuntas \\
\hline 29 & Syfa Bela Fajrin & 80 & B & Tuntas \\
\hline 30 & Wahyu Saputra & 55 & E & Tidak tuntas \\
\hline 31 & Widya Rosita Fajrin & 75 & C & Tuntas \\
\hline 32 & Wulan Suci Rmafhani & 75 & C & Tuntas \\
\hline 33 & Yudha haristia & 80 & B & Tuntas \\
\hline 34 & Yudhi dwi Handika & 85 & A & Tuntas \\
\hline 35 & Maliki & M. Gufran magribi & B & Tuntas \\
\hline 36 & & Cidak tuntas \\
\hline
\end{tabular}

Berdasarkan tabel 4.4. diatas menunjukan bahwa tingkat ketuntasan individu yang mencapai standar ketuntasan nilai $\geq 70$, siswa yang mendapatkan nilai tertinggi dengan jumlah 3 orang "sangat baik", siswa dengan jumlah 17 orang "baik", siswa yang mendapatkan nilai sedang dengan jumlah 8 orang "cukup" dan siswa yang mendapatkan nilai dibawah ketuntasan nilai $\geq 70$ dengan jumlah 8 orang yang tergolong masih "kurang" atau rendah. Dikarenakan masih ada beberapa siswa yang masih rendah hasil belajarnya untuk itu diperlukan perbaikan ke siklus selanjutnya. 
Tabel 4.5. Data hasil belajar siswa melalui ketuntasan klasikal pada siklus I.

\begin{tabular}{|c|c|c|c|}
\hline $\begin{array}{c}\text { Jumlah } \\
\text { Siswa }\end{array}$ & $\begin{array}{c}\text { Banyak siswa } \\
\text { yang tuntas }\end{array}$ & Nilai rata-rata & $\begin{array}{c}\text { Ketuntasan } \\
\text { Klasikal }\end{array}$ \\
\hline 36 & 28 orang & 72,78 & $77,78 \%$ \\
\hline
\end{tabular}

Dari tabel di atas, menunjukkan bahwa tingkat ketuntasan hasil/ prestasi belajar (kognitif) siswa masih belum mencapai target yang ditetapkan, yaitu $85 \%$ dari jumlah keseluruhan siswa di kelas mendapatkan nilai $\geq 70$. Untuk itu perlu dilakukan siklus selanjutnya.

d. Tahap Refleksi

Penerapan model Pembelajaran Kooperatif tipe team Quiz pada siklus I ini, masih belum optimal dan belum mencapai target yang telah ditetapkan. Hal ini disebabkan oleh adanya kekurangankekurangan. Pada siklus II akan diadakan penyempurnaan dan perbaikan terhadap kekurangan atau kendala-kendala yang muncul pada siklus I.

Adapun kekurangan guru dan siswa pada siklus I antara lain:

a) Guru kurang menyampaikan tujuan pembelajaran dan melakukan apersepsi atau mengkaitkan pengetahuan awal siswa dengan materi yang akan disampaikan. Dalam hal ini, guru masih kurang siap dan terlalu "takut" waktu yang tersedia tidak cukup. Sehingga arah atau tujuan pembelajaran yang harus dikuasai oleh siswa tidak jelas. Untuk mengatasinya, guru harus berusaha untuk bisa mengkondisikan waktu yang tersedia, sesuai dengan RPP yang telah disusunnya.

b) Guru menyampaikan meteri pembelajaran dengan terlalu cepat tanpa memperhatikan kemampuan siswa dalam menangkap apa yang disampaikannya. Hal ini disebabkan oleh kebiasaan guru dalam kesehariannya yang berbicara terlalu cepat. Sehingga, dalam penyampaian materi ada siswa yang langsung mengkritik "Bu...cara menjelaskannya diusahakan lebih pelan, jangan terlalu cepat, biar kita bisa mengerti apa yang disampaikan”. 
Dengan demikian, guru menjadi sadar dan berusaha untuk lebih pelan, santai dan berusaha membaca kemampuan awal siswa dalam pembelajaran.

c) Pada waktu pelaksanaan diskusi kelompok, siswa masih malu untuk bertanya kepada siswa lain atau teman kelompoknya apabila mereka belum mengerti. Untuk mengatasinya, guru memberikan motivasi untuk terus aktif bertanya apabila belum jelas dan menyelesaikan tugas kelompok dengan baik sesama anggota kelompoknya.

d) Siswa masih kurang aktif dalam bekerjasama dengan anggota kelompoknya, serta masih kurang berusaha untuk mencari berbagai informasi untuk memecahkan masalah yang ada. Hal ini terlihat hanya beberapa siswa saja yang dominan untuk mengerjakan tugas kelompoknya. Untuk mengatasinya, guru memberikan bimbingan dan motivasi kepada siswa untuk lebih aktif dalam bekerjasama untuk memecahkan masalah yang ada dalam diskusi kelompok. Sehingga hasil diskusi yang akan dipresentasikannya menjadi menarik dan lebih baik, sesuai dengan apa yang diharapkan.

e) Disamping kekurangan-kekurangan dari aktivitas guru di atas, ada juga kelebihan yang harus dipertahankan atau ditingkatkan lagi, diantaranya yaitu: a) guru sudah mengecek kesiapan belajar siswa dengan baik, b) mengembangkan topik sesuai dengan apa yang akan didiskusikan oleh siswa dalam kelompoknya, c) membagi siswa menjadi beberapa kelompok kemudian memberika topik yang akan di diskusikan pada masing-masing kelompok, d) memotivasi siswa dalam persentasi dan mengumpulkan tugas tepat waktu, dan e) bersama-sama siswa menyimpulkan materi/ pokok bahasan yang telah dibahas sebelumnya.

\section{Penutup}

Berdasarkan hasil penelitian yang dilakukan di kelas VI SDN 2 Kota Bima, maka dapat ditarik simpulan sebagai berikut :

1. Terjadi peningkatan kemampuan guru dalam mengelola proses pembelajaran di kelas VI SDN 2 Kota Bima pada mata pelajaran Pendidikan Agama Islam melalui penerapan Pembelajaran Kooperatif tipe Team Quiz Peningkatan aktivitas guru dalam 
menerapkan metode TQ ini terlihat pada presentase, yakni pada siklus I baru mencapai $61,11 \%$

2. Penerapan Pembelajaran Kooperatif tipe Team quiz dalam melihat aktifitas siswa kelas VI SDN 2 Kota Bima dalam menjalankan diskusi dalam pembelajaran Pendidikan Agama Islam dapat terlihat pada presentase ketuntasan yaitu pada siklus I mencapai $61,11 \%$

\section{DAFTAR PUSTAKA}

Depdiknas. Metode Pembelajaran Kewarganegaraan. Jakarta, Direktorat Tenaga Kependidikan, 2005.

Hamalik. Proses Belajar Mengajar. Jakarta, Sinar Grafindo Offset, 2004.

Hamalik. Guru dalam Proses Belajar Mengajar. Bandung, Sinar Baru Algensindo, 2009.

http://www.idonbiu.com/2009/05/pembelajarancooperativelearning. html

Rifa'i. 2009. Belajar dan Faktor- faktor yang Mempengaruhinya. Jakarta, Rineka Cipta.

Slavin. 2008. Cooperative LearningTeori, Riset, dan Praktik. Bandung, Nusa Media, 2008.

Sudjana. Metode Pengajaran Nasional. Bandung, Jemmars, 1990.

Sudrajat. Evaluasi Hasil Belajar. Surabaya, Usaha Nasional, 2006.

Suharsimi Arikunto. Penelitian Tindakan Kelas. Jakarta, Bumi Aksara, 2010.

Suprijono. Pendidikan Bagi Anak Berkesulitan Belajar. Jakarta, PT Rineka Cipta, 2009.

Suyanto. Menjelajah Pembelajaran Inovatif. Surabaya, Masmedia Buana Pustaka, 2009. 